\title{
クモ膜下出血で発症した椎骨脳底動脈解離性動脈瘤の 病理所見とその特異性
}

一 5 剖検例よりの検討一

\author{
遠藤 俊郎, 扇一 恒章, 野村 耕章 \\ 栗本 昌紀, 西嶌美知春, 高久 晃
}

\section{A Pathological Study of Intracranial Vertebro-basilar Artery Dissecting Aneurysms with Subarachnoid Hemorrhage: Report of Five Autopsied Cases}

Shunro ENDo, M.D., Tsuneaki OGIICHI, M.D., Hiroaki Nomura, M.D., Masanori Kurimoto, M.D., Michiharu Nishijima, M.D., and Akira TAKARU, M.D.

Depertment of Neurosurgey, Toyama Medical and Pharmaceutical University, Toyama, Japan

Summary : Five autopsied cases of dissecting aneurysms with spontaneous subarachnoid hemorrhage $(\mathrm{SAH})$ of the intracranial vertebro-basilar artery are reported, and the literature is reviewed to investigate the pathological characteristics and pathogenesis of this lesion. The location and pathological features of the aneurysms differed in each presented case. Subadventitial hemorrhage associated with $\mathrm{SAH}$, multiple noncontiguous intramural hemorrhages, and new vessels in and around the arterial wall were noteworthy findings in our series. All 20 reported autopsided cases of the vertebrobasilar artery have a dissection between the media and adventitia with a rupture site in the thin adventitia. Seventeen had disruption of the entire arterial wall, but the remaining three had no apparent luminal connection. The clinico-pathological features of this disease are various. Based on the pathological investigations of these reported cases, the pathogenesis of this lesion is discussed. Intramural hemorrhage associated with dissection without luminal connection should not be disregarded as a causative factor.

\section{はじめに}

頭蓋内椎骨脸底動脈解離性動脈瘤は近年注目される疾患 で，クモ膜下出血 $(\mathrm{SAH})$ 発症例の頻度も決して低いもの ではないことが知られてきた 314)8110)14)15)18)。しかし，解 離性動脈瘤と診断される頭蓋内病変は極めて多様な形態を 示し，その真の病態についてはなおあいまいな点が多い. 本報告では，SAH で発症し死亡に至った 5 剖検例の血管
Key words :

- dissecting aneurysm

- subarachnoid hemorrhage

- vertebro-basilar artery

- pathology 

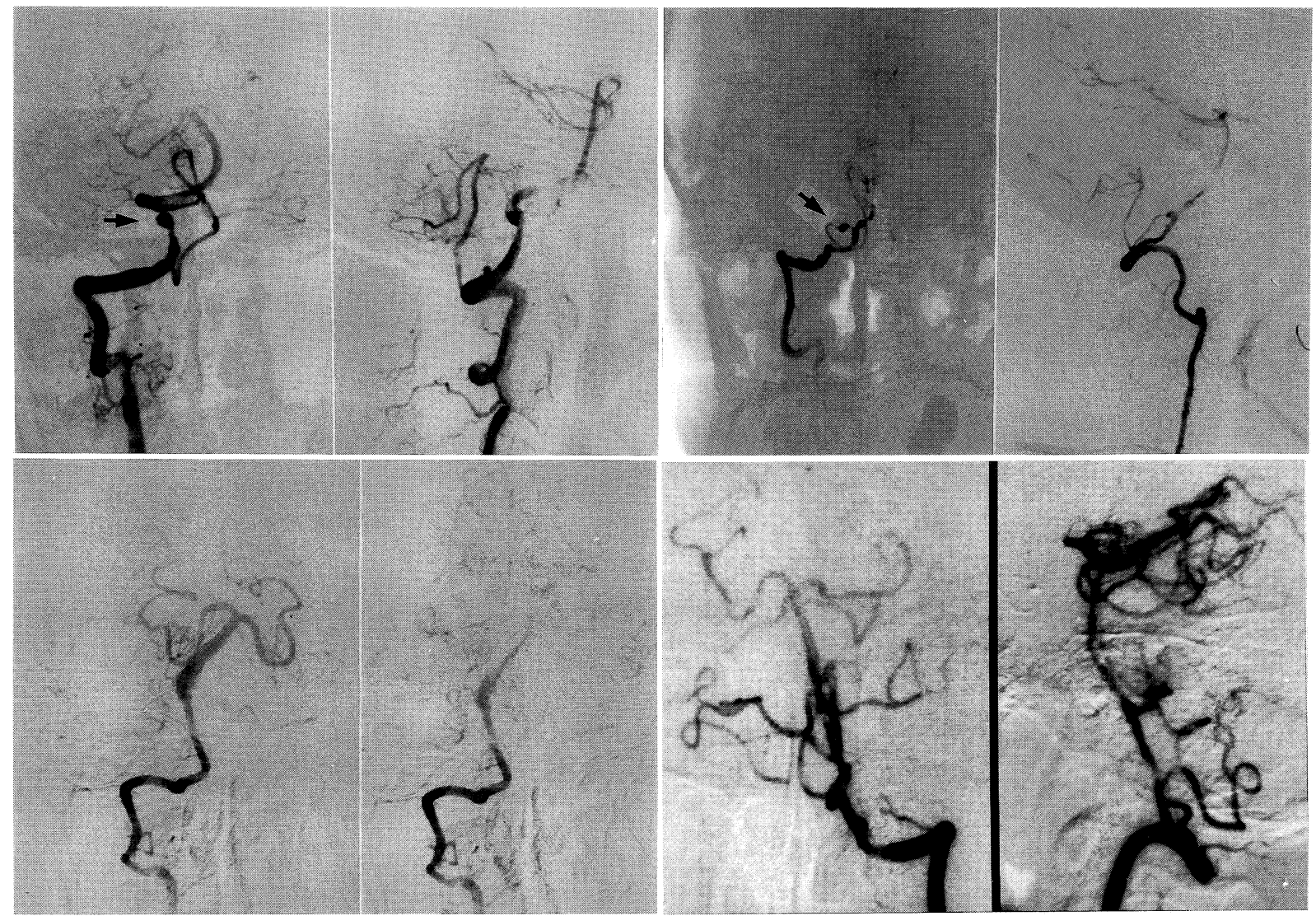

Fig. 1 Vertebral angiographic findings of the four cases. Left upper (Case 1): "Pearl and string sign" of a dissecting aneurysm of the right vertebral artery (arrow); Right upper (Case 2): An aneurysmal dilatation at the origin of the posterior inferior cerebellar artery (arrow) and irregular narrowing of the right vertebral artery; Left lower (Case 3): Early and delayed arterial phase revealing a fusiform dilatation with abnormal filling persistence of the mid-basilar artery and narrowed segments proximal to this lesion; Right lower (Case 5): Irregular narrowing and the suspicious finding of double feeling of the left vertebral and basilar artery.

であり，うち 4 例で施行された血管撮影所見を Fig. 1 に 示す.

$<$ 症例 $1>54$ 歳, 男.

高血圧の既往を有し，突然の激しい頭痛発作および意識 障害で発症した．血管撮影で，後下小脳動脈分岐部末梢側 の椎骨動脈に典型的 “pearl and string”の所見を認め, この部の解離性動脈瘤と診断された。開頭手術を行い，検 查部位に一致する椎骨動脈に漏斗状破裂動脈瘤の形成を認 め, 椎骨動脈 trapping 術を施行した。患者は発症約 1 カ 月後, 肝機能障害および DIC のため死亡した.

\section{<症例 2>52 歳, 男.}

突然の頭痛発作㧍よび一過性意諳障害で発症した，血管 撮影で右後下小脳動脈起始部の動脈瘤様球状膨隆所見㧍よ び周囲椎骨動脈に不規則な狭窄所見を認めた。開頭手術で 血管写所見に一致する後下小脳動脈瘤病変を認め, 椎骨動
脈の proximal clipping を施行した. 本例は両側頭蓋外内 頸動脈にも広範な数珠状の狭窄像を認め, 左内頸動脈閉塞 による脳梗塞のため死亡した。

$<$ 症例 3 $>61$ 歳, 男.

高血圧の既往を有し, 突然の激しい頭痛発作で発症した。 血管撮影で右椎骨動脈末梢合流部より脳底動脈下半部にか け，管径の狭小化抢よび double lumen を思わせる造影剂 の停滞所見を認め, 椎骨脳底動脈解離性動脈瘤の存在を疑 った.しかし同部位に対する開頭手術では, 厚いクモ膜下 血腫は認めるものの, 合流部付近の椎骨脳底動脈に明らか な動脈瘤形成や壁破綻の所見は観察できなかった。手術は 後下小脳動脈末梢で右椎骨動脈 clipping のみを行い終了 したが，患者は術 5 日後，重篤な再出血発作をきたし死亡 した。 
$<$ 症例 $4>47$ 歳, 男.

amyloid angiopathy による全身合併症を有した症例で, 突然の意識障害・呼吸停止で発症, 回復を見ることなく死 亡した．血管撮影は施行されておらず，剖検所見により脳 底動脈壁破綻による出血が確認された。

\section{$<$ 症例 $5>60$ 歳, 男.}

糖尿病の既往を有し, 突然の意識障害で発症した。血管 撮影で左椎骨動脈末梢より脳底動脈全体に及ぶ管径の狭小 化を認め, その変化は脳底動脈中央部より先端部でより顕 著であった. 矢状断 MRI 像で, 脳底動脈の走行に一致し て壁内解離性出血を思わせる所見も観察された。 CT ・ MRI で脳底動脈先端部に連続する血腫像を認め, 椎骨動 脈より伸展する解離性病变が脳底動脈先端で破綻したもの と考えた. 左椎骨動脈 clipping を目的に後頭下開頭手術 を施行したが, 観察可能範囲の椎骨脳底動脈壁に解離病変 を疑わせる所見は全く認められなかった．患者は発症 2 力 月後に肺合併症を併発し死亡した.

以上 5 症例において, 剖検時に頭蓋内脳底部主幹動脈の 肉眼的所見を確認の後, 椎骨脳底動脈の連続切片を作成し 病理組織学的検索を行った. 染色は hematoxylin and eosin および elastica-van Giesonを用い, 主として動脈壁 内出血およびこれにかかわる変化を中心に検討した。

\section{結果}

\section{1. 剖検時肉眼的所見}

4 例 (症例 1 ～）でクモ膜下出血に連続する動脈壁破綻 部位が確認された. 症例 1,2 は術中所見で確認されたご とく, 椎骨動脈および後下小脳動脈に漏斗状動脈瘤の形成 を認め, この部が出血点であった. 症例 3,4 は脳底動脈 に凝血塊の付着した限局性壁破綻部位を認めた，症例 3 の 病変は，血管撮影所見からは予測できない変化であった。 なおいずれの病変も動脈分岐部とは無関係の限局性変化で あり, 周囲動脈壁には解離性病変の伸展を思わせる所見は 観察されなかった. 症例 5 は肉眼所見で出血点は確認でき なかった。

症例 3 は動脈硬化性所見が顕著であった. amyloidosis の既往を有した症例 4 は, 脳底動脈の著しい壁肥厚および 蛇行を示した. また症例 2,3,4の3 症例で, 出血部位と は無関係の椎骨脳底動脈壁に複数の血豆状膨隆变化を認め た.

\section{2. 血管病理所見}

各症例の出血部位を中心とする椎骨脳底動脈壁病理組織 所見は以下のごとくであった.

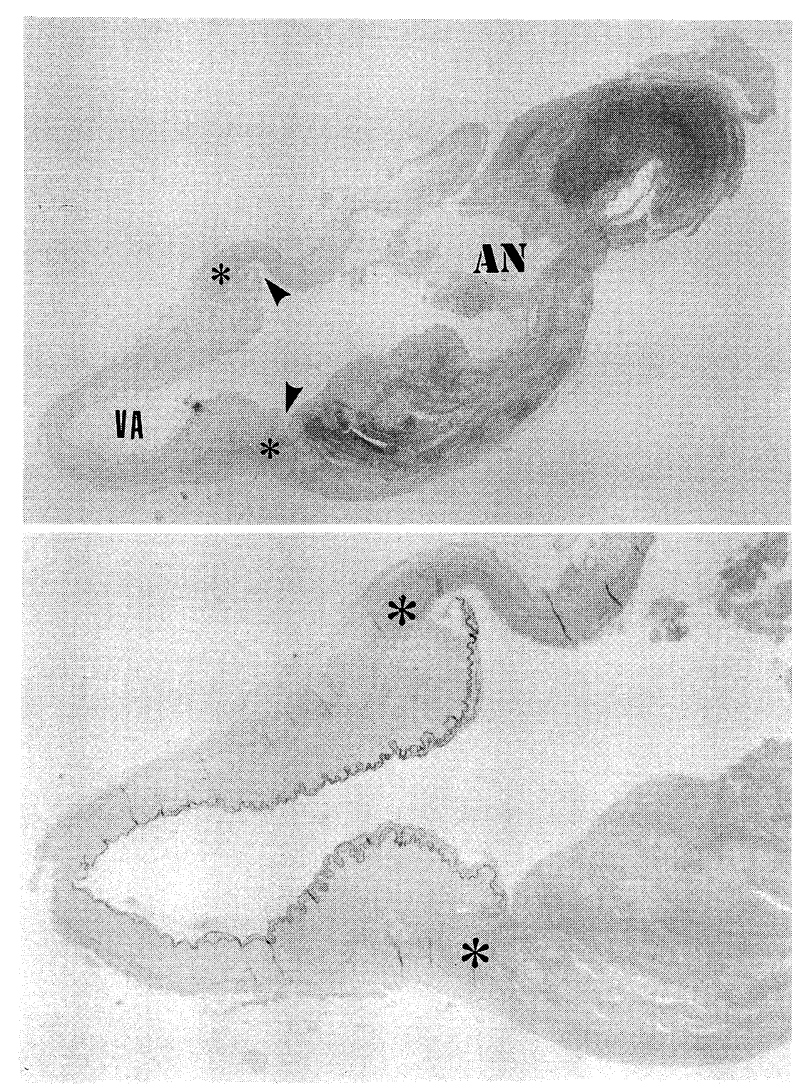

Fig. 2 Case 1. Photomicrograph and close-up of the arterial lesion at the site of rupture; vertebral artery (VA) with widespread disruption of the arterial wall (arrow) and hematoma between the media adventitia $(*)$ accompanied by aneurysm formation (AN). Elastica-van Gieson stain.

症例 1 : 椎骨動脈は動脈瘤への移行部で全層性の壁破綻 を示していた．破綻部の中外膜間に一部限局性の壁内出血 を認めるものの，周囲動脈壁に及ぶ解離性出血の所見は認 められなかった. 動脈瘤は, その基部で壁の一部に中膜・ 外膜の残存を認めるものの, 大部分は血栓化した pseudoaneurysm の形態であった(Fig. 2).

症例 2 : 後下小脳動脈は, 動脈瘤様膨隆部で全周性に内 弾性板および中膜の破綻をきたし, 膨隆部壁の一部では外 膜構造も失われていた。しかしこのような変化は膨隆部の みに限局し, 中枢側および末梢側の後下小脳動脈壁に異常 所見は認められなかった。なお肉眼所見で椎骨動脈に血豆 状膨隆を示した部位に一致して, 中膜・外膜間に存在する 限局性壁内出血の所見を認めた(Fig. 3).

症例 3 : 脳底動脈出血部位に一致して, 中膜・外膜間に 広がる壁内出血および外膜の一部破綻を認めた. また椎骨 および脳底動脈の一部に, 外膜の破綻を伴わない中膜・外 膜間壁内出血を認め, その一部は肉眼所見で観察された血 豆状膨隆病変部に一致していた，脳底動脈の一部には, 動 脈硬化性の著しい内膜肥厚および plaque 内出血も認めら 


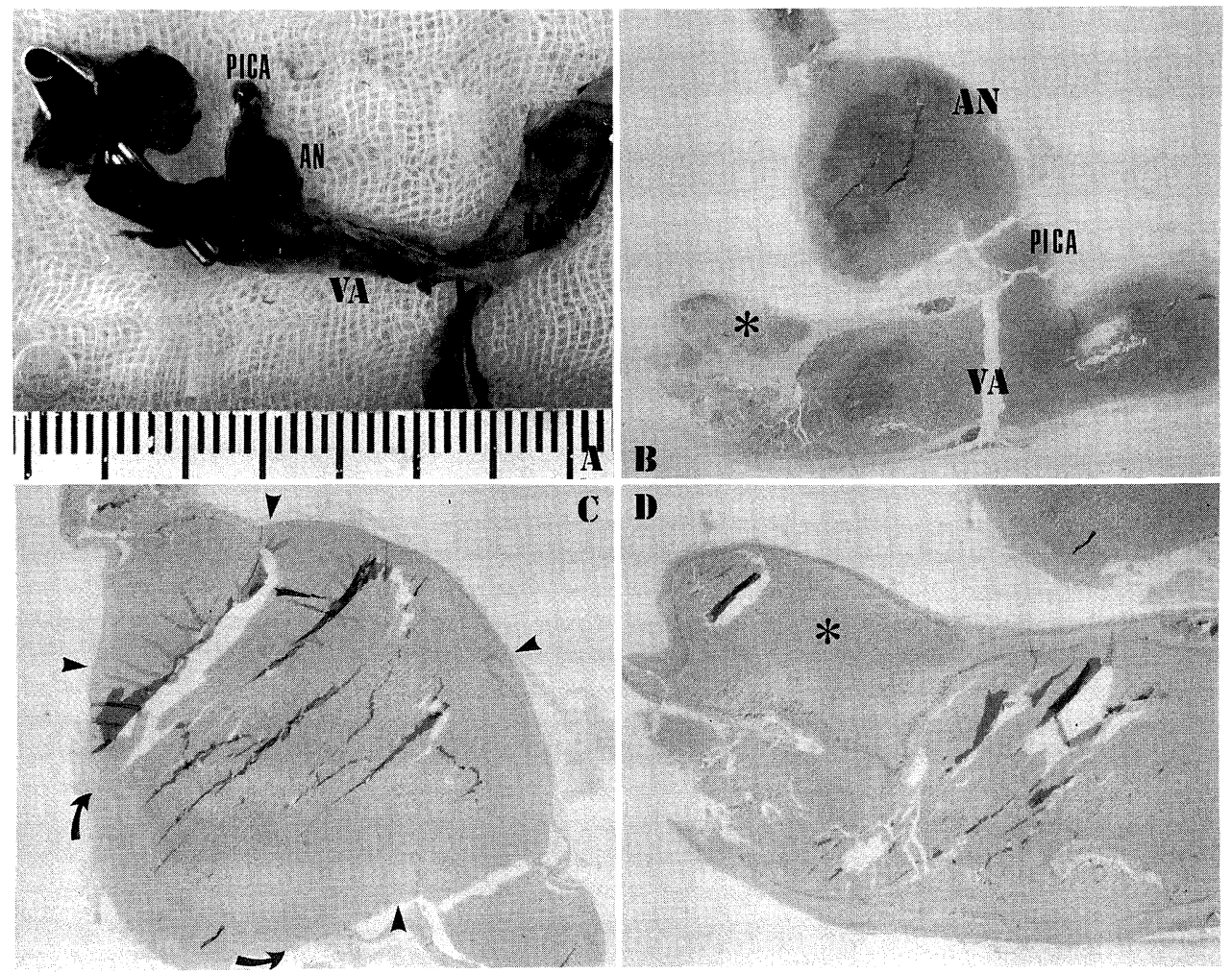

Fig. 3 Case 2. A: Postmortem photograph of the lesion. B-D: Photomicrographs of the aneurysm and vertebral artery; The dilated PICA aneurysm demonstrated widespread disruption of the internal elastic lamina and media (arrow heads) including a site of adventitial disruption (arrow) (C). Dissecting hemorrhage localized in the subadventitial space of the vertebral artery $(*)$ can been seen $(\mathrm{D})$. VA: vertebral artery, AN: aneurysm, PICA: posterior inferior cerebellar artery. Hematoxylin eosin Elastica-van Gieson stain.

れた。これらの壁内出血は限局性の変化で血管内腔とは連 続せず，また各病変間にも連続性は認められなかった (Fig. 4).

症例 4 ：脳底動脈出血部位に一致して, 全層性壁破綻の 所見を認めた。この部の変化は限局性で, 周辺動脈壁内に 伸展する解離性出血の所見は認められなかった。 または椎 骨脳底動脈全般にわたり, 中膜の変性・菲薄化㧍よび内弾 性板断裂の所見が顕著であり, 中・外膜間に限局する複数 の壁内小出血所見も認められた(Fig. 5).

症例 $5:$ 脳底動脈先端分岐部に, 内弾性板の断裂, 中膜 変性抢よび陳旧性の壁内小出血を示す個所が認められた。 椎骨脳底動脈の他の部位はいずれも正常の壁構造が保たれ ており, また発症時の CT ・ MRI で描出された凝血塊の 部位も一致することにより, この部が出血点であったと推 定した (Fig. 6).

以上 5 症例で観察された動脈壁内出血はいずれも限局性 の変化で，その形態は Fig. 7 に示すごとく 4 型に分類さ れた。 またいずれの症例も椎骨動脈外膜に, vasa vasorum と考えられる豊富な血管網の発達を見た。

\section{考察}

動脈壁の解離性出血病変には, 内膜一中膜間の解離によ り内腔の狭窄・閉塞をきたすものと, 中膜一外膜間の解離 により壁外方への外膜突出あるいは破綻・出血をきたすも のがある. 山浦らは頭蓋内椎骨動脈系に解離性動脈瘤の発 生頻度が高いことを指摘するとともに, 彼らの経験した 24 例中 21 例が SAH 発症例であったと報告している ${ }^{18)}$. 頭蓋内動脈は他部位の動脈に比し明らかに壁が薄く，また 外弾性板を欠くなどの特徵を持ち, 壁内出血のクモ膜下腔 への破綻は十分に予測されるところである(3)/7)9 177)。しか し SAH で発症した椎骨脳底動脈解離性動脈瘤報告例の中 で, 病理組織所見の検討がなされたものはこれまで 20 例 にすぎず12) 25)9)11) 16)19)，本疾患の形成機序や破綻に至る 過程など，その病態についていまだ定説は得られていない のが現状である。

従来の報告で示された本疾患の主たる病理所見としては (1) 全例でクモ膜下腔に連続する壁内出血を中膜一外膜間に 認める. (2) 20 例中 17 例で, 出血部位の動脈壁は全層性 

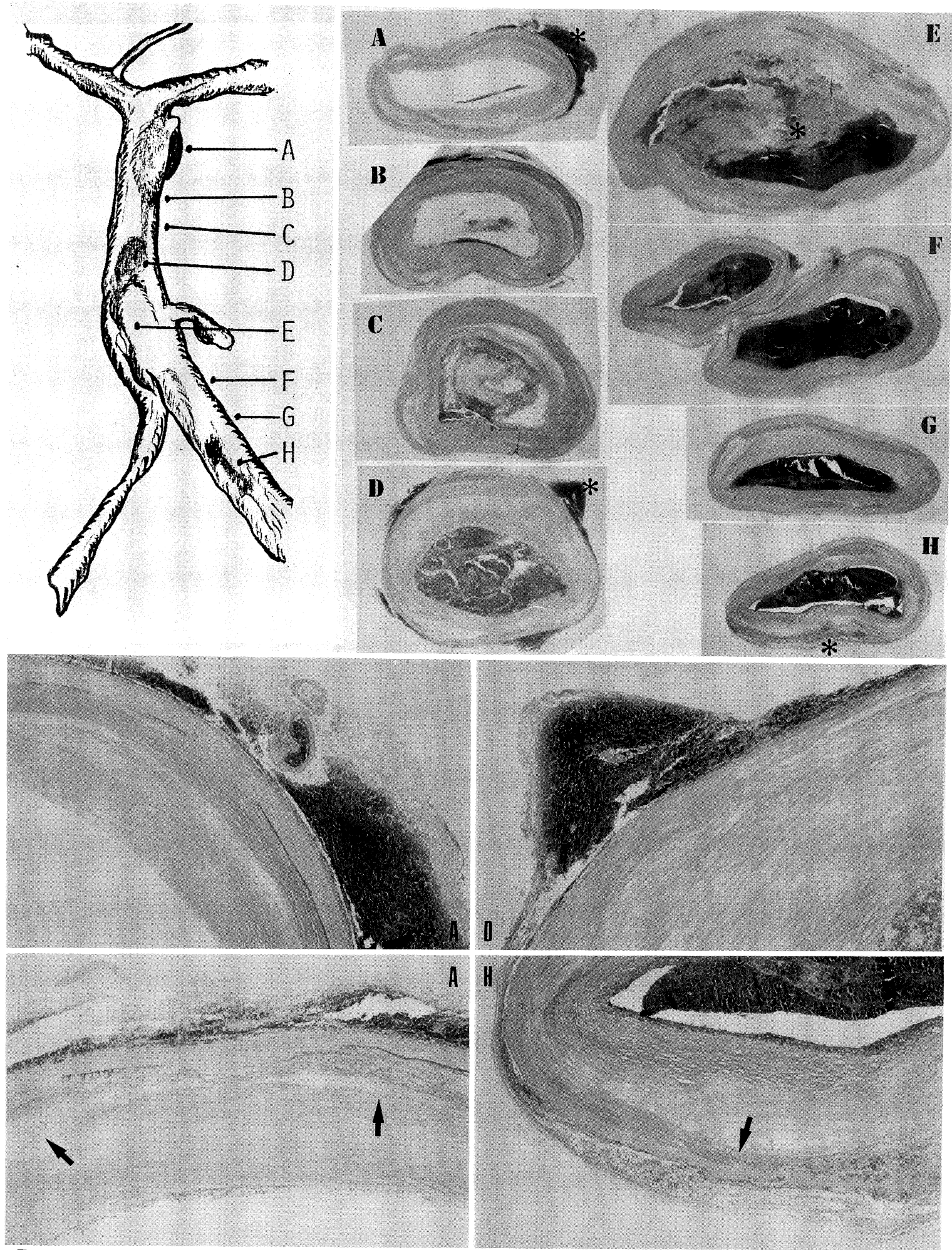

Fig. 4 Case 3. Photomicrograph of serial sections of the vertebrobasilar artery and a close-up of the three sections (A, $\mathrm{D}, \mathrm{H})$. Multiple lesions of subadventitial or intraatheromatous plaque hemorrhage $(*)$ without mutual continuity can be seen. Unusual arterioles and neovascularization of the intra- and peri-arterial wall can also be seen (arrow). Elastica-Masson's stain. 


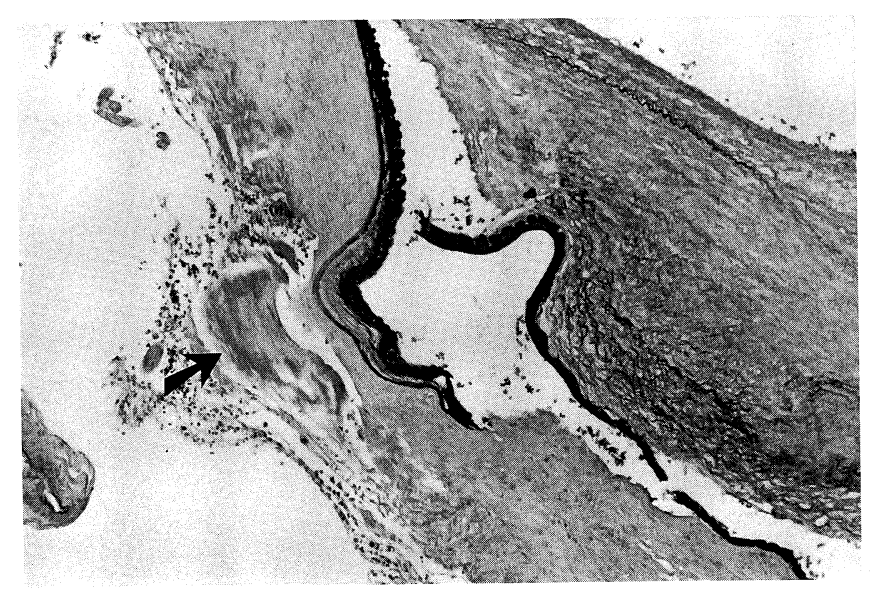

Fig. 5 Case 4. Photomicrographs of the basilar artery lesion at point of rupture: Totally interruption of the arterial wall (arrow) and degenerative changes of elastical lamina and medial tissue can be seen. Elastica-van Gieson stain.
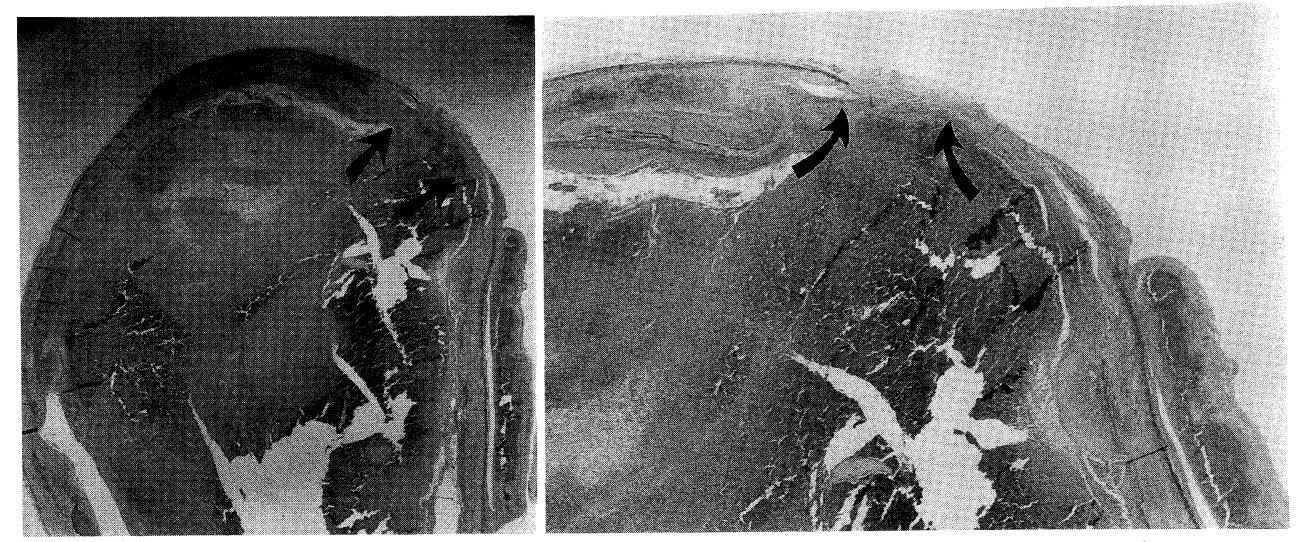

Fig. 6 Case 5. Photomicrographs of the basilar artery lesion at suspicious point of rupture: (arrow) Interruption of the arterial wall, restored changes of the media, and old hematoma between media and adventitia can be seen. Elastica-van Gieson stain.
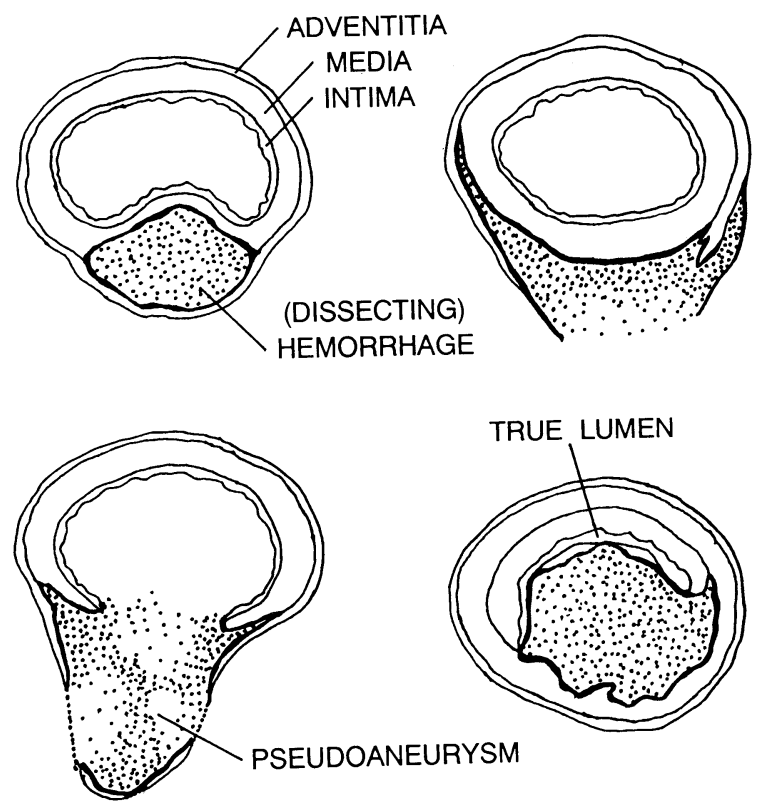

Fig. 7 The four types of dissecting hemorrhage in the vertebrobasilar artery system observed in the presented series; subaventitial hemorrhage localized in the arterial wall (left upper), ruptured hemorrhage between the media and adventitia with or without luminal connection (right upper \& left lower), and hemorrhage in the atheromatous plaque (right lower). 
破綻を示し, 動脈瘤様膨隆所見を伴う。しかし血管内腔と の連続性が観察されない出血例も3 例報告されている ${ }^{2)}$ 19). なおこれら 3 例では, 内膜の肥厚を伴う動脈硬化性変化が 顕著であった. (3) 関連する所見として, 周辺部動脈壁に 見られる動脈硬化性変化 2) 14) 15) 16) 19), 内弾性板・中膜の 欠損 $\left.{ }^{11)} 14\right)$ 15) , 中膜変性 ${ }^{8)}$ 11) -15) , 外膜新生血管の発達 ${ }^{19)}$ な どがあげられている. 今回我々の提示した 5 症例において も，これらの報告例と同様に様々な壁内出血と壁破綻の形 態が観察された．特に肉眼所見の血豆状壁膨隆に一致して 内腔およびクモ膜下腔いずれにも連続しない中膜-外膜間 の限局性壁内出血が多数認められたことは, 従来の報告に は見られない興味ある所見と考えられた。

本疾患の発生機序に関し, 従来よりいくつかの仮説が報 告されている. 多くの報告は, なんらかの機序で内腔と連 続する壁破綻が起こり，この部を起点に血流の流入による

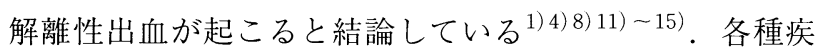
患で認められる内弾性板や中膜の欠損・変性, あるいは高 血圧の関与なども報告されている 1)4) 8) 14). 特に佐々木ら は 5 例の剖検例を報告し, 内膜・中膜に起きる破綻が本疾 患の形成に関与する最も重要な要因と述べている ${ }^{14)}$. し かしこのような考えは, 内腔と連続性を有しない病変の発 生機序については説明が不可能である。この点に関し Yonasらは, vasa vasorumあるいは中膜変性に伴う新生 血管の破裂が壁内出血をひき起こし，これに続く解離性病 変の形成をみるとの考えを報告している ${ }^{19)}$ 。このような 考えに対し，現在は否定的意見が多い. しかし本仮説は 様々な形態の壁内出血病変の病態が説明可能であり, また 椎骨動脈は頭蓋内動脈の中で vasa vasorum を有する特異 的な部位であることなど，注目すべき点も多い.

一方，今回の病理組織学的検討では，クモ膜下出血をき たした壁破綻部位は限局性で，周囲の動脈壁内に連続・伸 展するいわゆる解離性出血の所見はほとんど認められなか った. 現在臨床的に頭蓋内解離性動脈瘤と診断される病変 が，はたして他の体部大血管と同様に真の解離性病変を有 するものか否か, 病名の妥当性を含め疑問点が多い. いず れにせよ本疾患の病態・形成機序についてはあいまいな点 が多く, 今後の検討を要する課題であろう.

* 今回報告した症例 1 ～，㧍よび論文の要旨は既に “Neurosurgery”に投稿，揭載予定であることを㧍ことわりする.

\section{文献}

1) Adams HP Jr, Aschenbrener CA, Kassel NF, et al: Intracranial hemorrhage produced by spontaneous dissecting intracranial aneurysm. Arch Neurol 39: 773-775, 1982

2) Alexander CB, Burger PC. Goree JA: Dissecting aneurysms of the basilar artery in two patients. Stroke 10: 294-299, 1979

3) Anson J, Crowell RM: Cervicocranial arterial dissection. Neurosurgery 29: 89-96, 1991

4) Berger MS, Wilson CB: Intracranial dissecting aneurysms of the posteerior circulation. Report of six cases and review of the literature. J Neurosurg 61: 882-894, 1984

5) Farrell MA, Gilbert JJ, Kaufmann JC: Fatal intracranial dissection: Clinical pathological correlation. J Neurol Neurosurg Psychiatry 48: 111-121, 1985

6) Fisher CM, Ojemann RG, Roberson GH: Spontaneous dissection of cervico-cerebral arteries. Can J Neurol Sci 5: 9-19, 1978

7) Friedman WA, Day AL, Quisling RG, et al: Cervical carotid dissecting aneurysms. Neurosurgery 7: 207-214, 1980

8) Friedman AH, Drake CG: Subarachnoid hemorrhage from intracranial dissecting aneurysm. J Neurosurg 60 : 325334, 1984

9) Hart RG, Easton JD: Dissections of cervical and cerebral arteries. Neurologic Clinics 1: 155-182, 1983

10) Hosoda K, Fujitu S, Kawaguchi $T$, et al: Spontaneous dissecting aneurysms of the basilar artery presenting with a subarachnoid hemorrhage. Report of two cases. J Neurosurg 75: 628-633, 1991

11）井手 豊, 福島武雄, 山本正昭, ほか：中膜ムコイド変性 を認めた椎骨動脈解離性動脈瘤の 1 例. Neurol Med Chir (Tokyo) 26: 888-894, 1986

12) Manz HJ, Luessenhop AJ: Dissecting aneurysm of intracranial vertebral aterty: Case report and review of literature. J Neurol 230: 25-35, 1983

13) Pilz P: Idiopathische medianekrose intrakranieller und zervikaler Artericen. Wien Klin Wochenschr 94: 455-458, 1982

14) Sasaki O, Ogawa H, Koike T, et al: A clinicopathological study of dissecting aneurysms of the intracranial vertebral artery. J Neurosurg 75: 874-882, 1991

15) Shimoji $T$, Bando $K$, Nakajima $K$, et al: Dissecting aneurysm of the vertebral artery. Report of seven cases and angiographic findings. J Neurosurg 61: 1038-1046, 1984

16) Takita K, Shirato $H$, Akasaka $T$, et al: Dissecting aneurysm of the vertebrobasilar artery-A case report and review of previous cases. No To Shinkei 31: 1211-1218, 1979

17) Wilkinson IMS: The vertebral artery. Extracranial and intracranial structure. Arch Neurol 27: 392-396, 1972

18) Yamaura A, Watanabe $Y$, Saeki N: Dissecting aneurysms of the intracranial vertebral artery. J Neurosurg 72: 183188,1990

19) Yonas H, Agamanolis D, Takaoka $Y$, et al: Dissecting intracranial aneurysms. Surg Neurol 8: 407-415, 1977 